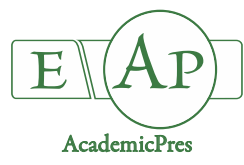

\title{
Intercropping of Faba Bean with Barley at Various Spatial Arrangements Affects Dry Matter and N Yield, Nitrogen Nutrition Index, and Interspecific Competition
}

\author{
Kalliopi GALANOPOULOU ${ }^{1}$, Anastasios S. LITHOURGIDIS ${ }^{2}$, \\ Christos A. DORDAS ${ }^{1 *}$ \\ ${ }^{1}$ Aristotle University of Thessaloniki, School of Agriculture, Laboratory of Agronomy, 54124 Thessaloniki, \\ Greece; chdordas@agro.auth.gr (*correspondingauthor) \\ ${ }^{2}$ Aristotle University of Thessaloniki, Farm of Thessaloniki, 57001 Thermi, Greece; lithour@agro.auth.gr
}

\begin{abstract}
Intercropping is the cultivation of two or more crop species on the same area of land, and can improve yield, forage quality, and soil health. Despite the fact that intercropping is an old practice, it received significant attention the last years because of the environmental impact that it has. However, the effect of the various spatial arrangements of the different species that are used in an intercropping system was not determined. The objective of the present study was to study the yield, growth and nitrogen $(\mathrm{N})$ uptake rate, $\mathrm{N}$ nutrition index (NNI) of barley, interspecific competition, quality and financial outcome of intercrops of faba bean (Vicia faba L. var. equina) and barley (Hordeum vulgare L.) with various spatial arrangements (1:1, 2:2, 2:1 alternate rows, and mixed in the same row). The land equivalent ratio (LER), relative crowding coefficient (K), actual yield loss (AYL) and system productivity index (SPI) values were greater for the FB:B intercrop of 2:1, indicating the advantage of intercropping in terms of dry matter and $\mathrm{N}$ yield. Sole cropping of barley showed a reduction in NNI by $7 \%$, whereas NNI for barley increased by an average of $14 \%$ in intercropping treatments. Based on biomass production and the competition indices for dry matter and N yield, and NNI the FB:B intercrop of 2:1 was more advantageous than faba bean and barley monocrops, as well as the other intercropping treatments that were tested.
\end{abstract}

Keywords: competition; financial yield; growth rate; indices; protein content

\section{Introduction}

In recent years, several environmental challenges such as reductions in soil, water, and air quality have been attributed to modern agriculture. Modern farmers, especially those in developed countries, use chemically intensive practices to maintain soil productivity, together with other management practices that decrease organic matter in the soil and increase soil erosion, acidification, and salinization (Dumanski et al., 1986). In addition, the sustainable management of plant nutrients such as nitrogen $(\mathrm{N})$, is challenging due to the increased costs of $\mathrm{N}$ fertilizers, coupled with $\mathrm{N}$ loss through ammonia volatilization, nitrous oxide emissions, and nitrate leaching (Fageria and Baligar, 2005). Therefore, it is important to develop sustainable and ecologically sound nutrient management practices that can be applied to large farms. For most ecosystems, one strategy that can address many of these concerns is the inclusion of grain legumes with cereal crops, a practice known as intercropping (Anil et al., 1998; Lithourgidis et al., 2011a; Brooker et al., 2015; Bedoussac et al., 2015).

Despite the fact that some studies have shown that intercrops have a significant yield advantage as compared with monocrops (Dordas and Lithourgidis, 2011; Lithourgidis et al., 2011a), other studies have shown that intercropping cannot produce the necessary yields (Mead and Willey, 1980; Midya et al., 2005). This is because the yield of an intercropping system depends on several factors, such as seeding density, crop species and genotypes, management practices, and the spatial arrangement of the individual crops (Herbert et al., 1984; Hauggaard-Nielson et al., 2001; Esmaeli et al., 2011; Brooker et al., 2015; Bedoussac et al., 2015). Mixed cropping and a 1:1 row arrangement (one row of each crop species) are common intercropping systems (Agegnehu et al., 2006). However, there are limited reports regarding the effects of various 
spatial arrangements on the productivity of the intercropping of grain legumes and cereals and on the competitive abilities of the crop species used in a given intercropping system (Banik et al., 2006; Esmaeili et al., 2011).

Intercropping has a particular advantage in that the species used do not compete for the same resource niche and thus use environmental resources in complimentary ways (Hauggaard-Nielsen et al., 2001; Bedoussac and Justes, 2011). The advantage of cereal-legume intercrops is due to the complementary use of $\mathrm{N}$ sources by the components of these intercrops (Bedoussac and Justes, 2010; Bedoussac et al., 2015). Intercropping has an advantage in low-input cropping systems where soil $\mathrm{N}$ is at low concentration. Under low soil $\mathrm{N}$ levels, legumes have a significant advantage as they can take up $\mathrm{N}$ from the atmosphere through biological nitrogen fixation and therefore show higher competitive ability compared with the cereals, which have higher competitive ability under high $\mathrm{N}$ levels (Hauggaard-Nielsen and Jensen, 2001; Bedoussac and Justes, 2011; Monti et al., 2016). In such intercropping systems, the soil $\mathrm{N}$ level is maintained at adequate levels because of the use of legumes (Hauggaard-Nielsen et al., 2001; Bedoussac and Justes, 2011). Moreover, under low N soil level cereals can be more competitive for $\mathrm{N}$ than legumes and can force legumes to take up $\mathrm{N}$ via $\mathrm{N}_{2}$ fixation (Hauggaard-Nielsen et al., 2009).

One of the ways that is used to determine the level of plant $\mathrm{N}$ nutrition is NNI (Nitrogen Nutrition Index) (Debaeke et al., 2006; Prost and Jeuffroy, 2007; Ziadi et al., 2008; Dordas, 2017). NNI can be calculated by dividing the actual plant $\mathrm{N}$ concentration by the critical plant $\mathrm{N}$ concentration $\left(\mathrm{N}_{\mathrm{c}}\right)$. Critical $\mathrm{N}$ concentration, defined as the minimum $\mathrm{N}$ concentration in the shoot biomass required for maximum growth rate, has been established for barley (Justes et al., 1997) $\mathrm{N}_{\mathrm{c}}=5.35 \times \mathrm{W}^{-0.442}$ where $\mathrm{W}$ is the total shoot biomass expressed in $\mathrm{Mg} \mathrm{DM} \mathrm{ha}{ }^{-1}$ (Dordas, 2017). The NNI is considered a reference tool for assessing plant $\mathrm{N}$ status. However, NNI has a major limitation at the farm level as the actual crop biomass and its $\mathrm{N}$ concentration at different growth stages need to be determined, which is quite difficult in many cases.

Intercropping is a system that was studied extensively the last years and many indices have been used to determine the advantages of intercropping systems as compared with monocrops (Weigelt and Jolliffe, 2003; Dhima et al., 2007; Bedoussac and Justes, 2011). However, most of these indices were based on dry matter. The use of the same indices based on $\mathrm{N}$ yield to determine the effects of intercropping on $\mathrm{N}$ utilization has not been explored as it can give useful information for the advantages of the intercropping systems in terms of $\mathrm{N}$ yield and resource use efficiency.

The objectives of the present work were: (i) to evaluate faba bean and barley in two monocropping systems and four intercropping systems in terms of dry matter yield, $\mathrm{N}$ yield, NNI, and protein content; (ii) to study the effect of various spatial arrangements intercropping systems on the growth rates of the two species; (iii) to assess the effect of competition among the component species of the various intercropping systems using the dry matter yield and $\mathrm{N}$ yield; and (iv) to assess the economic advantage provided by each intercropping treatment.

\section{Materials and Methods}

\section{Study site and crops management}

A field experiment was conducted at the University Farm of Thessaloniki in northern Greece (22 $59^{\prime}$ E, $40^{\circ} 32^{\prime}$ N) over two growing seasons (2009-2010 and 2010-2011). The experiment was established in a loam (L) soil (Typic Xerorthent) with $\mathrm{pH}$ of 7.8 , organic matter content of $14 \mathrm{~g}$ $\mathrm{kg}^{-1}, \mathrm{~N}^{-N^{2}} 340 \mathrm{mg} \mathrm{kg}$, $\mathrm{P}$ (Olsen) $29 \mathrm{mg} \mathrm{kg}^{-1}$, and $\mathrm{K} 180$ $\mathrm{mg} \mathrm{kg}$ (0 to $30 \mathrm{~cm}$ depth). The previous crop was durum wheat and after harvest, the straw was baled and removed. Before seeding, the cultivation area was moldboard plowed, harrowed and a cultivator was used. Nitrogen and P fertilizer were applied before seeding at rates of 80 and $40 \mathrm{~kg}$ $\mathrm{h}^{-1}$, respectively in form of diammonium phosphate (2010-0). The same field was used in both years but different plots were used each year. The field was uniform in terms of cultivation history and cropping systems that were used. There were no pesticides that were used and also no irrigation during both growing periods. Climatic data during the two growing seasons of the experimentation were recorded daily with an automatic weather station which was close to the experimental site and are reported as mean monthly data for both years in Fig. 1.

Faba bean (cv. 'Polycarpe') and barley (cv. 'Thessaloniki') as well as intercrops of faba bean with barley in one seeding ratio (50:50) based on seed weight, under four different spatial arrangement, were sown around the end of November for both years. The seeding rates that were used were for barley and faba bean monocrop 160 and 120 $\mathrm{kg} \mathrm{ha}{ }^{-1}$, respectively, whereas the seeding rates for each intercrop were 80 and $60 \mathrm{~kg} \mathrm{ha}^{-1}$ of barley and faba bean respectively. The treatments were the following:

1. Faba bean monocrop

2. Barley monocrop

3. Faba bean - Barley $1: 1$ alternate rows (FB:B 1:1)

4. Faba bean - Barley 2:2 alternate rows (FB:B 2:2)

5. Faba bean - Barley 2:1 alternate rows (FB:B 2:1)

6. Faba bean - Barley mixed in the same row (FB:B mixed)

The corresponding seeding rate of monocrops was 432 and 34 seeds per $\mathrm{m}^{2}$ for barley and faba bean, respectively. The corresponding seeding rate for intercrops was 216 and 17 seeds per $\mathrm{m}^{2}$ of barley and faba bean respectively. The germination rate was about $90 \%$.

The experimental design was a randomized complete block with six treatments (two monocrops and four intercrops of faba bean with barley) replicated four times. Plot size was $5 \mathrm{~m} \mathrm{x} 2 \mathrm{~m}$ and plots were separated by a $2.5 \mathrm{~m}$ buffer zone. Both species were sown at the same day in rows $25 \mathrm{~cm}$ apart. All crops were kept free of weeds by implementing hand hoeing, where necessary. Faba bean had been cultivated in the field for the last three years and thus natural nodulation occurred (Lithourgidis and Dordas, 2010; Dordas and Lithourgidis, 2011). The nodulation was verified by examining the root system and observing nodules that were formed during the growing period. 
1118

\section{Growth rate and dry matter yield}

For the determination of growth rate of the different species used in the intercropping treatments, faba bean and barley were sampled four times at $0,3,6$, and 9 weeks after tillering (WAT). During these sampling barley was at tillering, jointing, and booting and milk stage respectively. In addition, faba bean at the same periods was at stem elongation, first flower open, development of fruit and ripening of fruit respectively. The area that was harvested was $0.5 \mathrm{~m}^{2}$ of each plot. More specifically, plants were cut to the ground level manually and the different species were separated by hand to determine fresh weight of each species in each plot. Dry matter yield was determined by harvesting an area of $2 \mathrm{~m}^{2}$ from each plot when faba bean was at podsetting stage and barley at milk stage which is around midMay of each growing season. The samples were dried at 70 ${ }^{\circ} \mathrm{C}$ to constant weight to determine the relative water content.

Nitrogen uptake, protein yield and $N$ utilization efficiency

Nitrogen uptake was determined by multiplying the $\mathrm{N}$ concentration of the biomass by the dry matter yield. $\mathrm{N}$ concentration of was determined by measuring the total $\mathrm{N}$ content with the Kjeldahl method (Karlidag and Yildirim, 2007; Dordas and Lithourgidis 2011). Following crude protein concentration was determined by multiplying the $\mathrm{N}$ concentration by 6.25 (Karlidag and Yildirim, 2007; Dordas and Lithourgidis, 2011). Also N utilization efficiency (NUtE) for biomass accumulation was determined calculated according to using the following formula $\mathrm{NUtE}=\mathrm{DM} / \mathrm{N}$, where $\mathrm{DM}$ is the dry matter at harvest and $\mathrm{N}$ is the total $\mathrm{N}$ that was taken up by the crop both based on the same area of land (López-Bellido and López Bellido, 2001).

Nitrogen Nutrition Index (NNI)

The NNI of the crop of barley was determined by dividing the $\mathrm{N}$ concentration of the shoot biomass by the critical $\mathrm{N}$ concentration $\left(\mathrm{N}_{\mathrm{c}}\right)$ (Dordas, 2017). Critical N concentration, the minimum $\mathrm{N}$ concentration required to achieve maximum shoot growth, was defined as a function of shoot biomass as proposed for barley by Justes $e t$ al. (1997). $\mathrm{N}_{\mathrm{c}}=5.35 \times \mathrm{W}^{-0.442}$ where $\mathrm{W}$ is the total shoot biomass expressed in Mg DM ha ${ }^{-1}$. NNI was determined for the three sampling at 0,3 , and 6 weeks after tillering because at this stage there is high demand for $\mathrm{N}$ from the crop and most of $\mathrm{N}$ is taken up by the soil at this stage.

Land equivalent ratio (LER) for dry matter and $N$ yield

One of the commonly used index is the land equivalent ratio (LER) and is used as the criterion for intercropping advantage, as LER shows the efficiency of the intercropping system for using the environmental resources compared with monocropping. When LER is greater than one the intercropping favours the growth and yield of the intercropped species as it uses the environmental resources more efficient. Whereas when LER is lower than one the intercropping negatively affects the growth and yield of the species (Dhima et al., 2007). The LER was calculated as:

$\mathrm{LER}=\left(\mathrm{LER}_{\mathrm{fb}}+\mathrm{LER}_{\mathrm{b}}\right), \quad \mathrm{LER}_{\mathrm{fb}}=\left(\mathrm{Y}_{\mathrm{fbi}} / \mathrm{Y}_{\mathrm{fb}}\right), \quad \mathrm{LER}_{\mathrm{b}}=$ $\left(\mathrm{Y}_{\mathrm{bi}} / \mathrm{Y}_{\mathrm{b}}\right)$, where $Y_{f b}$ and $Y_{b}$ are the yields of faba bean and barley, respectively, as monocrops and $Y_{f b i}$ and $Y_{b i}$ are the yields of faba bean and barley, respectively, as intercrops.

Also LER can be calculated on nitrogen yield basis and land equivalent ratio for $\mathrm{N}$ yield (LERN) was determined according to Bedoussac and Justes (2011) which indicates a possible $\mathrm{N}$ yield advantage of intercrops, as follows:

$\mathrm{LERN}=\mathrm{NY}_{\mathrm{bi}} / \mathrm{NY}_{\mathrm{b}}+\mathrm{NY}_{\mathrm{fb}} / \mathrm{NY}_{\mathrm{fb}}$

where $N Y_{b}$ and $N Y_{f b}$ are the crop $N$ yields for barley $(b)$ and faba bean $(\mathrm{fb})$ grown in monocrops and $\mathrm{NY}_{\mathrm{bi}}$ and $\mathrm{NY}_{\mathrm{fbi}}$ are the $\mathrm{N}$ yields of the crops grown in intercrops. A LERN $>1$ shows a $N$ yield advantage of the intercropping system whereas a $L E R N<1$ indicates a $N$ yield disadvantage. The LERN is the sum of the partial LERN of the individual crops in the intercrop. The partial LERN indicates the relative competitive ability of individual crops regarding $\mathrm{N}$ yields in intercrops.

Relative crowding coefficient $(K)$ for dry matter and $N$
yield
The relative crowding coefficient $(\mathrm{K})$ for dry matter and $\mathrm{N}$ yield is used to measure the relative dominance of one species over the other in an intercrop (Ghosh, 2004). The K was calculated as:

$\mathrm{K}=\mathrm{K}_{\mathrm{fb}} \cdot \mathrm{K}_{\mathrm{b}}, \quad \mathrm{K}_{\mathrm{fb}}=\mathrm{Y}_{\mathrm{fbi}} \mathrm{Z}_{\mathrm{bi}} /\left(\mathrm{Y}_{\mathrm{fb}}-\mathrm{Y}_{\mathrm{fbi}}\right) \mathrm{Z}_{\mathrm{fbi}}, \quad \mathrm{K}_{\mathrm{b}}=$ $\mathrm{Y}_{\mathrm{bi}} \mathrm{Z}_{\mathrm{bi}} /\left(\mathrm{Y}_{\mathrm{b}}-\mathrm{Y}_{\mathrm{bi}}\right) \mathrm{Z}_{\mathrm{bi}}$

where $Z_{\mathrm{fbi}}$ is the sown proportion of faba bean in intercrop and $\mathrm{Z}_{\mathrm{bi}}$ the sown proportion of barley in intercrop. There is a yield advantage when $\mathrm{K}$ is greater than one, when $\mathrm{K}$ is equal to one there is no yield advantage, and when it is less than one there is a disadvantage in efficient resource use resulting in relative yield loss. Similar to LER, K was calculated on $\mathrm{N}$ yield basis by replacing dry matter yield by $\mathrm{N}$ yield.

\section{System productivity index (SPI)}

System productivity index (SPI) is an index used for assessing intercrops as it standardizes the yield of the secondary crop (barley) in terms of the primary crop (faba bean) (Agegnehu et al., 2006) and is calculated as:

SPI $=\left[\left(\mathrm{Y}_{\mathrm{b}} / \mathrm{Y}_{\mathrm{fb}}\right) \cdot \mathrm{Y}_{\mathrm{fbi}}\right]+\mathrm{Y}_{\mathrm{bi}}$

where $Y_{b}$ and $Y_{f b}$ are the mean yield of barley and faba bean in monocrop and $Y_{b i}$ and $Y_{f b i}$ are the mean yield of barley and faba bean in mixed culture. In addition, SPI was calculated on $\mathrm{N}$ yield basis.

\section{Actual yield loss (AYL)}

In addition, Banik et al. (2000) found another index the actual yield loss (AYL) which can provide better information than other indices used to evaluate the competition between and within component crops and also can determine the behaviour of the different species used in intercropping. AYL was determined with the following formula (Banik et al., 2000):

$$
\begin{aligned}
& \mathrm{AYL}=\mathrm{AYL} \mathrm{L}_{\mathrm{b}}+\mathrm{AYL} \mathrm{L}_{\mathrm{b}}, \\
& \mathrm{AYL}_{\mathrm{bb}}=\left\{\left[\left(\mathrm{Y}_{\mathrm{fb}} / \mathrm{Z}_{\mathrm{bi}} /\left(\mathrm{Y}_{\mathrm{fb}} / \mathrm{Z}_{\mathrm{b}}\right)\right]-1\right\},\right. \\
& \mathrm{AYL}_{\mathrm{b}}=\left\{\left[\left(\mathrm{Y}_{\mathrm{b}} / \mathrm{Z}_{\mathrm{bi}}\right) /\left(\mathrm{Y}_{\mathrm{b}} / \mathrm{Z}_{\mathrm{b}}\right)\right]-1\right\}
\end{aligned}
$$

When AYL has positive values indicates an advantage of the intercrop and when AYL has negative values indicates disadvantage of the intercrop. Similar to LER and the other 
indices, AYL was calculated on $\mathrm{N}$ yield basis by replacing dry matter yield by $\mathrm{N}$ yield.

\section{Economic indices}

None of the abovementioned competition indices provides any information about the economic advantage of an intercropping system. For this reason, the monetary advantage index (MAI) and the intercropping advantage (IA) index were determined with the following formulas (Banik et al., 2000; Ghosh, 2004):

MAI $=$ (value of combined intercrops) $\mathrm{x}$ (LER-1)/LER $\mathrm{P}_{\mathrm{b}}$

$\mathrm{IA}=\mathrm{IA}_{\mathrm{b}}+\mathrm{IA}_{\mathrm{fb}}, \quad \mathrm{IA}_{\mathrm{fb}}=A \mathrm{AL}_{\mathfrak{b}} \cdot \mathrm{P}_{\mathrm{fb}}, \quad \mathrm{IA}_{\mathrm{b}}=A \mathrm{AL}_{\mathrm{b}}$.

$\mathrm{P}_{\mathrm{fb}}$ is the commercial value of faba bean silage (the current price is $€ 44$ per $\mathrm{Mg}$ ), and $\mathrm{P}_{\mathrm{b}}$ is the commercial value of barley silage (the current price is $€ 32.5$ per $\mathrm{Mg}$ ). Value of combined intercrops was calculated as: $\left(\mathrm{Y}_{\mathrm{fb}} \cdot \mathrm{P}_{\mathrm{fb}}\right)+\left(\mathrm{Y}_{\mathrm{bi}} \cdot \mathrm{P}_{\mathrm{b}}\right)$.

\section{Statistical analyses}

All data were analyzed by the ANOVA method according to a $2 \times 7$ factorial approach (growing season $\mathrm{x}$ treatments) with a split plot arrangement with four replications per treatment combination. The growing seasons were considered as the main plots and the seven treatments the split plots (Steel et al., 1997). A combined analysis over growing season was carried out.

For the determination of the growth rate on dry matter basis and $\mathrm{N}$ uptake basis dry matter and $\mathrm{N}$ uptake were measured at four different dates (0, 3, 6, and 9 WAT). Dry matter yield and $\mathrm{N}$ uptake changes in barley and faba bean were determined by regressing dry matter yield and $\mathrm{N}$ uptake of each plant species against sampling time. A number of equations (linear, quadratic, hyperbolic, and logarithmic) were tested for their suitability to better describe the relationship between dry matter yield and $\mathrm{N}$ uptake over time. The equation with the highest value of the adjusted coefficient of determination $\left(R_{a d j}^{2}\right)$ and the smallest standard error of estimate was selected as the most appropriate (Hair et al., 1995). The significance level of all hypotheses testing procedures was preset at $P<0.05$. SPSS (1998, version 17) software was used for the analysis of variance (ANOVA).

\section{Results}

During the two growing seasons (2009 and 2010) the weather conditions were quite similar as rainfall was 321 $\mathrm{mm}$ for the 2009 and $306 \mathrm{~mm}$ for the 2010 growing season (Fig. 1). In addition, as the ANOVA showed that there was no treatment-growing season interaction and the treatment means were averaged across the two growing seasons and are presented.

\section{Growth rate}

The dry matter yield of barley and faba bean was increased from 0 to 6 WAT and then declined in most treatments. The comparisons of the models showed that the quadratic equation $\left(y=a+b x-c x^{2}\right)$ had the best fit with dry matter over time (Fig. 2). The initial growth rates of the two crop species were different in monocrops ( $\alpha$ values of 2.441 and 1.054 for barley and faba bean, respectively), as were the growth rates of barley and faba bean in monocrops ( $b$ values of 1.095 and 1.483, respectively). In the case of barley, there was no significant difference in initial growth among most intercropping treatments, with the exception of the $\mathrm{FB}: \mathrm{B}$ 2:1 treatment, which showed a lower level of initial growth (1.709). In the case of faba bean, the initial growth rate was higher in the monocrop as compared with the intercropping systems. Moreover, faba bean showed higher initial growth rates in the FB:B 1:1, FB:B 2:1, and FB:B 2:2 treatments than in the FB:B mixed intercropping system. Faba bean showed a higher growth rate when it grew as monocrop compared with when it grew in intercrops (Fig. 2).

\section{Dry matter, Nyield and crude protein}

The barley monocrop provided higher dry matter yield as compared with the faba bean monocrop (Table 1). Moreover, in most cases, dry matter yield was significantly affected in the various intercropping treatments. The greatest dry matter yield was obtained from the FB:B 2:1 intercrop $\left(6.06 \mathrm{Mg} \mathrm{ha}^{-1}\right)$, followed by the barley monocrop $\left(5.95 \mathrm{Mg} \mathrm{ha}^{-1}\right)$. In particular, the FB:B 2:1 intercrop produced, on average, about 13, 23, and 39\% more dry matter yield than the FB:B 2:2 and 1:1 and FB:B mixed intercrops, respectively (Table 1 ). The proportion of faba bean plants was affected by intercropping treatment and was highest in the FB:B 2:1 intercropping treatment.

Nitrogen yield, which was measured via the $\mathrm{N}$ accumulated in shoots, followed a different trend in the case of intercrops and monocrops. It was increased in the faba bean monocrop and decreased in the barley monocrop and FB:B mixed intercropping system (Table 2). Among the intercropping treatments, the highest accumulated $\mathrm{N}$ yield was found in the case of the FB:B 2:1 treatment, followed by the FB:B 2:2 treatment. The faba bean proportion was lower when it was measured as dry matter than when it was measured as $\mathrm{N}$ yield due to higher $\mathrm{N}$ concentration of faba bean. When measured via $\mathrm{N}$ yield, faba bean proportion increased by between $18 \%$ and $52 \%$. When measured via dry matter proportion, faba bean proportion increased between 9 and 34\% (Tables 1,2). NUtE was lowest in the FB monocrop and highest in the barley monocrop, and this value showed significant differences among intercropping systems (Table 2).

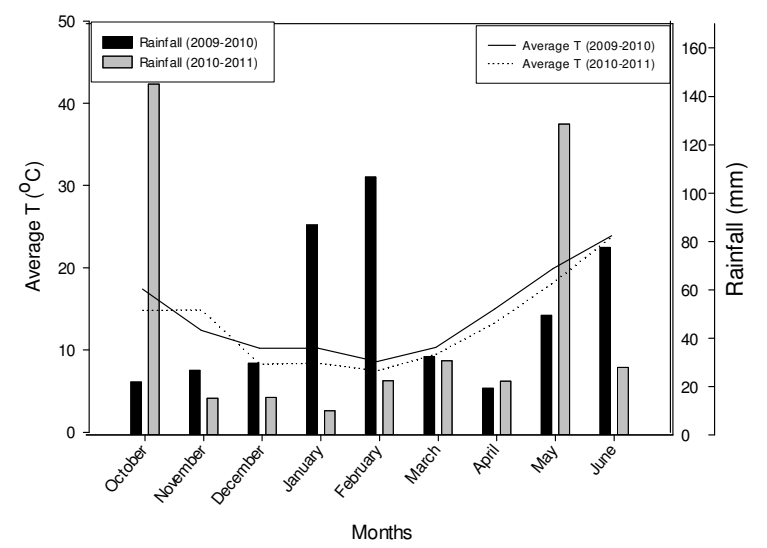

Fig. 1. Monthly rainfall and mean air temperature during the two growing seasons of the experiments in Thessaloniki, Greece 

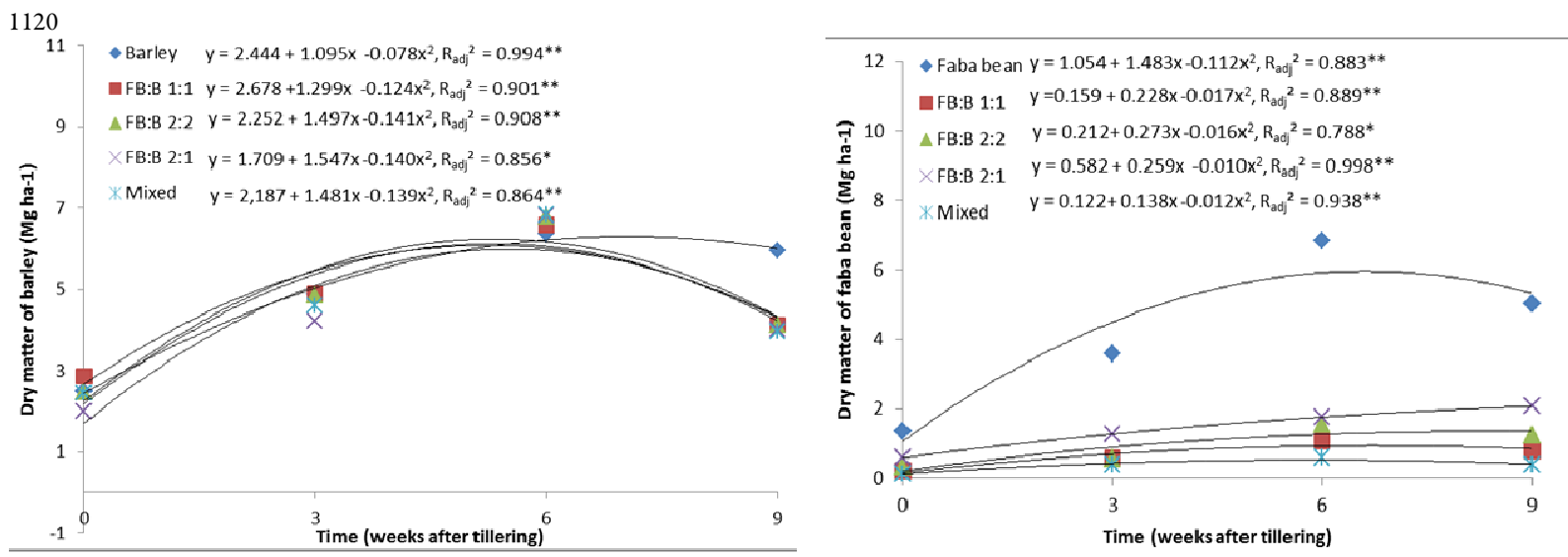

Fig. 2. Temporal patterns in dry weight of monocultures and mixtures of barley with faba beans at different intercropping systems. Means are averaged over two growing seasons and four replicates. Lines describe quadratic equations $\left(y=a+b x-c x^{2}\right),\left({ }^{*}\right.$, ${ }^{* *}$, ${ }^{* *}$ significant at the $0.05,0.01$, and 0.001 probability levels, respectively), FB; faba bean, B; barley, Faba bean - Barley 1:1;

FB:B 1:1; Faba bean - Barley 2:2; FB:B 2:2; Faba bean - Barley 2:1; FB:B 2:1; Faba bean - Barley mixed; Mixed

Table 1. Dry matter yield for monocrops and intercrops of faba bean with barley in different treatments and faba bean proportion. Means are averaged over two growing seasons

\begin{tabular}{ccccc}
\hline Crop & \multicolumn{2}{c}{ Dry matter yield $\left(\mathrm{Mg} \mathrm{ha}^{-1}\right)$} & \multicolumn{2}{c}{ Faba bean proportion } \\
\cline { 2 - 5 } & Faba bean & Barley & Total & $(\%)$ \\
\hline Faba bean & 5.01 & - & 5.01 & 100 \\
Barley & - & 5.95 & 5.95 & - \\
Faba bean - Barley 1:1 & 0.79 & 4.13 & 4.92 & 16 \\
Faba bean - Barley 2:2 & 1.23 & 4.12 & 5.35 & 23 \\
Faba bean - Barley 2:1 & 2.06 & 4.00 & 6.06 & 34 \\
Faba bean - Barley mixed & 0.39 & 3.96 & 4.35 & 9 \\
\hline & & & 0.70 & \\
\hline LSD 0.05 & 0.23 & 0.53 & & \\
\hline
\end{tabular}

Table 2. Nitrogen yield, crude protein concentration and yield, faba bean proportion in terms of $\mathrm{N}$ yield and $\mathrm{N}$ utilization efficiency (NUtE) for monocrops and intercrops of faba bean with barley in different treatments. Means are averaged over two growing seasons

\begin{tabular}{|c|c|c|c|c|c|c|c|}
\hline \multirow{2}{*}{ Crop } & \multicolumn{3}{|c|}{$\mathrm{N}$ yield $\left(\mathrm{kg} \mathrm{ha}^{-1}\right)$} & \multicolumn{2}{|c|}{ Crude protein } & \multirow{2}{*}{$\begin{array}{c}\begin{array}{c}\text { Faba bean } \\
\text { proportion }\end{array} \\
\%)\end{array}$} & \multirow[t]{2}{*}{ NUtE } \\
\hline & Faba bean & Barley & Total & $\begin{array}{c}\text { Concentration } \\
\left(\mathrm{g} \mathrm{kg}^{-1} \mathrm{DM}\right)\end{array}$ & $\begin{array}{c}\text { Yield } \\
\left(\mathrm{kg} \mathrm{ha}^{-1}\right)\end{array}$ & & \\
\hline Faba bean & 158.8 & - & 158.8 & 198.1 & 993 & & 31.55 \\
\hline Barley & - & 66.5 & 66.5 & 69.8 & 416 & - & 89.49 \\
\hline Faba bean - Barley 1:1 & 25.6 & 55.5 & 81.1 & 103.0 & 507 & 31.62 & 60.68 \\
\hline Faba bean - Barley 2:2 & 35.3 & 59.9 & 95.2 & 111.3 & 595 & 37.06 & 56.17 \\
\hline Faba bean - Barley 2:1 & 61.8 & 56.0 & 117.8 & 121.5 & 736 & 52.46 & 51.44 \\
\hline Faba bean - Barley mixed & 12.1 & 56.6 & 68.5 & 98.5 & 428 & 17.63 & 63.46 \\
\hline LSD 0.05 & 5.3 & 4.5 & 6.3 & 13.8 & 107 & & 4.06 \\
\hline
\end{tabular}

Crude protein concentration and protein yield $(\mathrm{CP})$ were the highest in the faba bean monocrop $\left(198.1 \mathrm{~g} \mathrm{~kg}^{-1}\right.$ of DM and $992.6 \mathrm{~kg} \mathrm{ha}^{-1}$, respectively) (Table 2). On the other hand, barley had the lowest CP concentration $\left(69.8 \mathrm{~g} \mathrm{~kg}^{-1}\right.$ of $\mathrm{DM})$. In addition, there was an increase in $\mathrm{CP}$ concentration in the intercropping treatments, especially in FB:B 2:2 and FB:B 2:1. Also, among intercropping treatments, the highest protein yield was found in $\mathrm{FB}: \mathrm{B} 2: 1$ $\left(736 \mathrm{~kg} \mathrm{ha}^{-1}\right)$ and followed by FB:B 2:2 (595 $\left.\mathrm{kg} \mathrm{ha}^{-1}\right)($ Table 2).

\section{Nitrogen uptake rate}

The effect of intercropping on $\mathrm{N}$ uptake (expressed per area basis) rate for each treatment is presented in Fig. 3. The comparisons of the models showed that the quadratic equation $\left(y=a+b x-c x^{2}\right)$ had the best fit with $\mathrm{N}$ uptake yield over time (Fig. 3). There was an increase in $\mathrm{N}$ uptake from 0 to 6 weeks of the cereal monocrops and their intercrops with faba bean and also a decreased from 6 to 9 WAT. The initial growth $(\alpha)$ of the cereal was higher at the barley monocrop and the lower initial growth was found at 
the FB:B 2:1 and the growth rate was higher at the FB:B 2:1 and FB:B 1:1. In addition, the initial growth was higher for faba bean monocrop and lower for the mixed treatment.

The growth rate for faba bean was higher at the faba bean monocrop and lower for the mixed treatment too (Fig. 3).

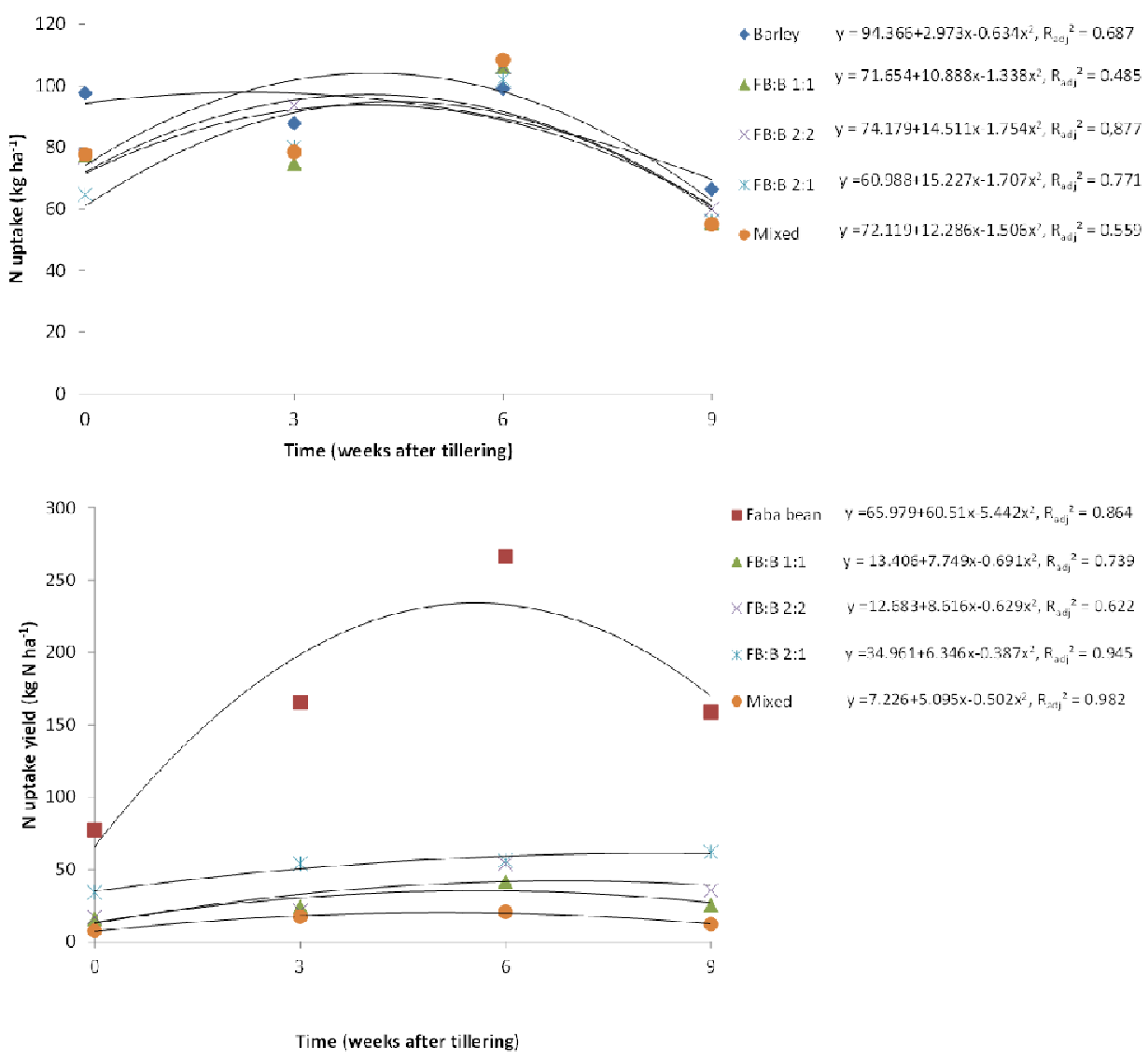

Fig. 3. Temporal patterns in $\mathrm{N}$ uptake of monocultures and mixtures of barley with faba beans at different intercropping systems. Means are averaged over two growing seasons and four replicates. Lines describe quadratic equations $(y=a+b x-c x 2),\left({ }^{*},{ }^{* *}\right.$, ${ }^{* * *}$ significant at the 0.05, 0.01 and 0.001 probability levels, respectively), FB; faba bean, B; barley, Faba bean - Barley 1:1; FB:B 1:1; Faba bean - Barley 2:2; FB:B 2:2; Faba bean - Barley 2:1; FB:B 2:1; Faba bean - Barley mixed; Mixed

\section{Nitrogen Nutrition Index}

Nitrogen Nutrition Index of barley was increased by an average of $14 \%$ with intercropping compared with the monocropping (Fig. 4). The highest increase in NNI for barley was found at the FB:B 2:1 treatment which was $21 \%$ and followed by the FB:B 2:2 treatment which was 14\%. NNI of barley monocropping was decreased from the first to the third sampling. In contrast, NNI for the intercropping treatments was increased in the three samplings.

\section{Competition indices}

The LER value for FB:B intercrops was greater than 1.00 only in the case of FB:B 2:1 (Fig. 5a). In this case, total LER was significantly higher than 1.00. The partial LER of faba bean was lower than 0.5 in all intercropping treatments. Also, for all treatments, the partial LER of barley was above 0.5 , and there were no differences between treatments.

When LER was calculated on the basis of $\mathrm{N}$ yield, the trend was similar to that seen with dry matter. The highest value found for FB:B 2:1, followed by FB:B 2:2, the lowest value was found for the $\mathrm{FB}: \mathrm{B}$ mixed intercropping system (Fig. 5b). LERN values based on $\mathrm{N}$ were higher than the LER on dry matter. The partial LERN for faba bean was in the same range as dry matter. However, in the case of barley, the LERN was higher than dry matter.

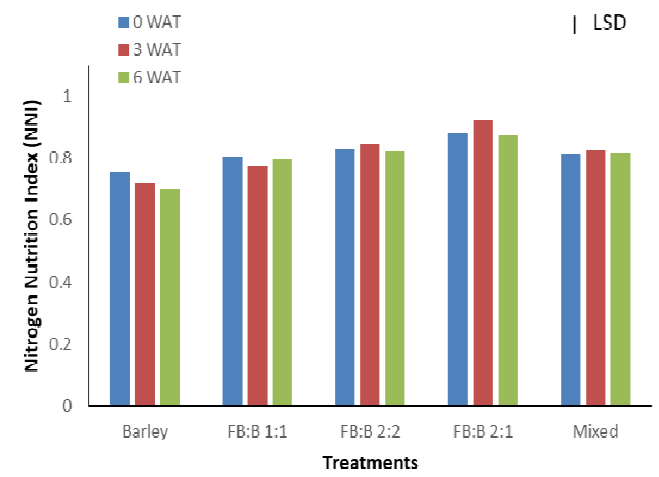

Fig. 4. Nitrogen nutrition values (NNI) of barley grown as sole crops and as intercrops at the tillering, jointing, and booting corresponding at 0,3 and 6 weeks after tillering (WAT) respectively. Means are averaged over two growing seasons and four replicates. where FB:B 1:1; Faba bean - Barley 1:1; FB:B 2:2; Faba bean - Barley 2:2; FB:B 2:1; Faba bean - Barley 2:1; Mixed; Faba bean - Barley mixed, where LSD is the Least Significant Difference at 0.05 significance level. 
1122

Relative crowding coefficient values followed a trend similar to that of the LER values in the case of faba bean. In particular, the $\mathrm{K}$ values were below 1.00 in the case of faba bean in all treatments (Fig. 6). However, for barley, the $\mathrm{K}$ value was above 1.00 , whereas the highest total $K$ value was found for FB:B 2:1. The situation was similar when $\mathrm{K}$ was calculated on the basis of $\mathrm{N}$ because the partial $\mathrm{K}$ for faba bean was below 1.00 and that for barley was above 1.00 . Total $\mathrm{K}$ was highest in the case of FB:B 2:1 when measured in terms of dry matter and $\mathrm{N}$ yield (Fig. 6).

A similar trend to that seen with LER, and $\mathrm{K}$ was also observed for AYL. In particular, AYL barley was higher than $A Y L_{\text {faba }}$ bean, and $A Y L_{b a r l e y}$ had positive values in all intercropped treatments, whereas the partial AYL of faba bean was negative (Fig. 7). The AYL $\mathrm{L}_{\text {total values were positive }}$ only in the case of the FB:B 2:1 intercropping system (Fig.
$7)$. The highest system productivity index (SPI) was found in the FB:B 2:1 intercrop (6.45), as seen in Table 6. Similarly, AYLN ${ }_{\text {total }}$ and $\mathrm{SPI}_{\mathrm{N}}$ for $\mathrm{N}$ had the highest values in the FB:B 2:1 intercrop (Fig. 7). General, all indices that were based on $\mathrm{N}$ yield were higher than the same indices based on dry matter yield.

\section{Economic indices}

The intercropping advantage (IA) for barley indicated that all intercrops were economic advantageous for barley in that their IA values were always positive. However, for faba bean, all partial IA values were negative, indicating economic disadvantage (Table 3 ). In addition, $\mathrm{IA}_{\text {total }}$ was the highest (3.22) in the FB:B 2:1 intercrop. A similar trend was noted for MAI values; MAI values were positive only in the FB:B 2:1 treatment (Table 3).

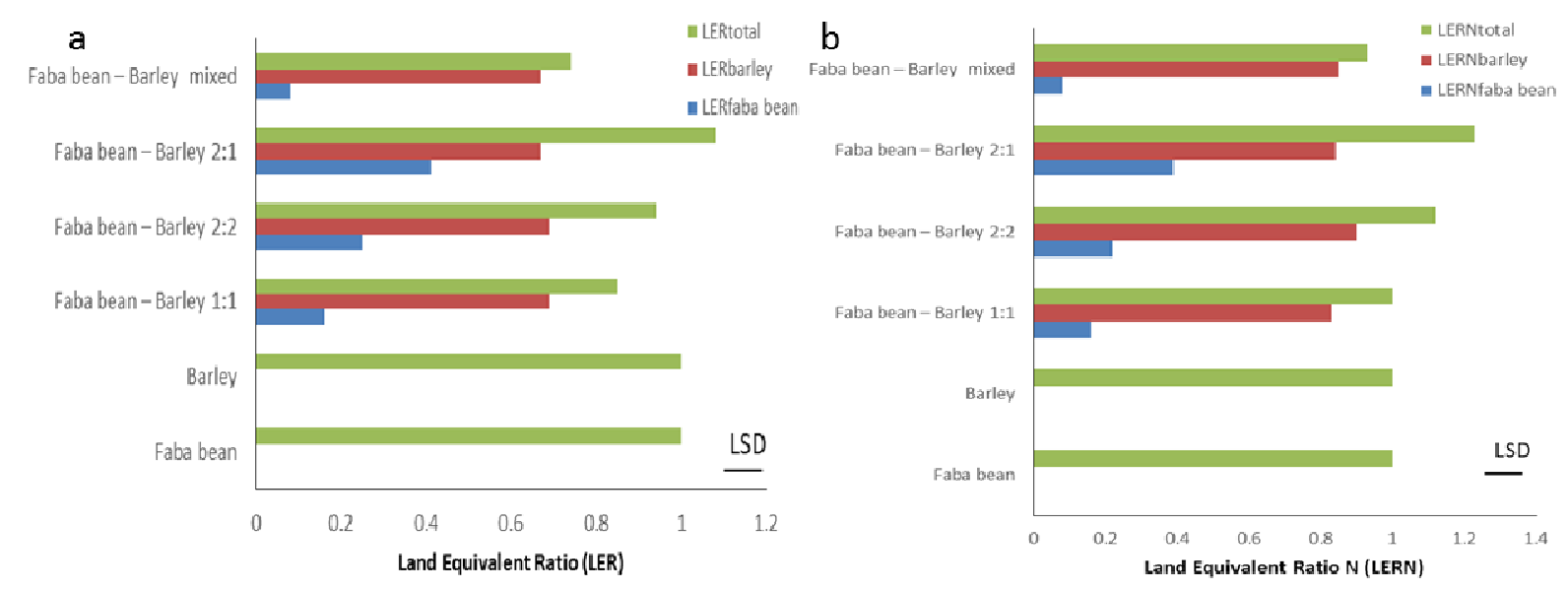

Fig. 5. a. Land equivalent ratio for monocrops and mixtures of faba bean with barley in four relay intercropping treatments for dry matter yield; b. Land equivalent ratio for monocrops and intercrops of faba bean with barley in four relay intercropping treatments for $\mathrm{N}$ yield. Means are averaged over two growing seasons, where LSD is the Least Significant Difference at 0.05 significance level
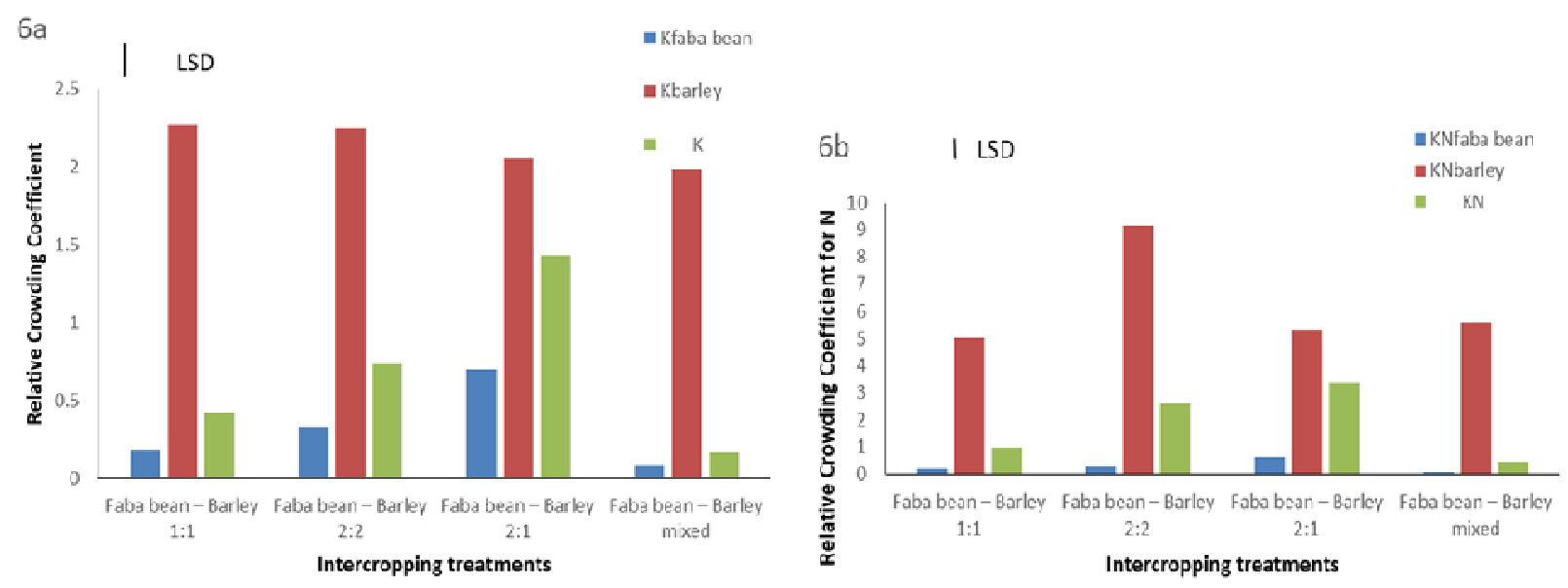

Fig.6. a. Relative crowding coefficient for monocrops and mixtures of faba bean with barley in four relay intercropping treatments for dry matter yield; b. Relative crowding coefficient for monocrops and intercrops of faba bean with barley in four relay intercropping treatments for $\mathrm{N}$ yield. Means are averaged over two growing seasons, where LSD is the Least Significant Difference at 0.05 significance level 
Table 3. Intercropping advantage and monetary advantage index for intercrops of faba bean with barley in four intercropping treatments. Means are averaged over two growing seasons

\begin{tabular}{|c|c|c|c|c|c|}
\hline & \multirow{2}{*}{ Crop } & \multicolumn{3}{|c|}{ Intercropping Advantage } & \multirow{2}{*}{ Monetary Advantage } \\
\hline & & IAfababean & IA barley & IA $A_{\text {total }}$ & \\
\hline & Faba bean - Barley 1:1 & -28.75 & 12.04 & -16.72 & -28.05 \\
\hline & Faba bean - Barley 2:2 & -21.38 & 11.93 & -9.45 & -11.87 \\
\hline & Faba bean - Barley 2:1 & -7.46 & 10.68 & 3.22 & 16.21 \\
\hline & Faba bean - Barley mixed & -35.46 & 10.26 & -25.20 & -48.03 \\
\hline & LSD0.05 & 1.34 & 2.3 & 0.85 & 2.56 \\
\hline \multicolumn{6}{|c|}{ Average procurement price per tone of faba bean $=€ 31$, barley $=€ 42$. } \\
\hline 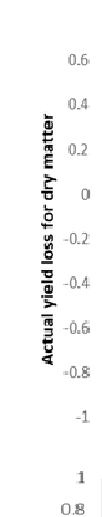 & Arbatley & 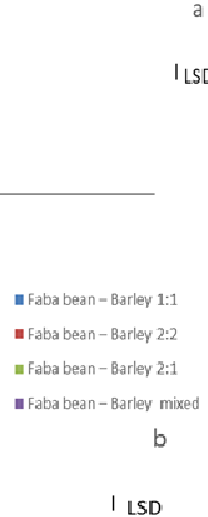 & \multicolumn{3}{|c|}{$\begin{array}{l}\text { other intercropping treatments. This could be attributed to } \\
\text { differences in competition between the two species involved } \\
\text { in the intercropping systems (Lithourgidis et al., 2006; } \\
\text { Bedoussac et al., 2015; Brooker et al., 2015). In addition, } \\
\text { barley affected the growth rate of faba bean because barley is } \\
\text { a more competitive species than faba bean, as suggested by } \\
\text { other studies in which faba bean was compared other cereals } \\
\text { (Lithourgidis and Dordas, 2010; Dordas and Lithourgidis, } \\
\text { 2012). Barley is a species that grows more quickly and earlier } \\
\text { in the season than faba bean (Lithourgidis and Dordas, } \\
2010 \text {; Dordas et al., 2012). Also, barley forms tillers after its } \\
\text { emergence and can thus compete with faba bean more } \\
\text { successfully (Lithourgidis et al., 2011b; Vlachostergios et al., } \\
\text { 2015). }\end{array}$} \\
\hline
\end{tabular}

\section{Dry matter, Nyield and crude protein}

The greatest dry matter yield of the intercrops was obtained in FB:B 2:1, and the lowest dry matter yield was found at the FB:B mixed system. This indicates that changing the arrangement of the two species affects the dry matter production of the species and also the competition between the species. In other studies, it was reported that the dry matter yield of intercrops of legumes and cereals were similar to or even lower than the yields of monocrops due to competition between the intercropped species (Vandermeer, 1990; Bedoussac et al., 2015; Brooker et al., 2015). However, there are several reports showing that intercrops can have higher dry matter yield than the respective monocrops which can be because of better resource utilization (Banik et al., 2006; Chapagain and Riseman, 2014). Faba bean proportions of were 16, 23, 34, and $9 \%$ (vs. the expected 50\%) in the FB:B 1:1, 2:2, 2:1, and mixed intercropping systems, respectively. The observed decrease of faba bean's contribution to the dry matter yield of the intercrops as compared with the expected $50 \%$ could be attributed to the stronger competitive ability of one species as compared to the other (Anil et al., 1998; Lithourgidis et al., 2011b). Furthermore, another possible explanation for faba bean's low level of contribution to the intercrops is that barley produced many tillers and grew more quickly earlier in the season, thus showing much greater competitive ability than faba bean (Lithorgidis and Dordas, 2010; Dordas and Lithourgidis, 2012). The decreased contribution of faba bean was not due to differences in faba bean emergence, because faba bean emerged similarly in all treatments (data not shown).

The highest $\mathrm{N}$ yield was found at faba bean monocrop, followed by the FB:B 2:1 intercrop, due to the higher $\mathrm{N}$ concentration of faba bean. In the other intercropping

treatments, nitrogen yield was much lower. In addition, the

Growth rate

The present study showed that the various arrangements of intercropping species can affect the growth rate of both species compared with their mono crops. Faba bean showed higher initial growth rate at the FB:B 2:1 treatment than the 
1124

proportion of faba bean's contribution was much higher when calculated based on $\mathrm{N}$ as compared to dry matter. This is due to the faba bean's much higher $\mathrm{N}$ concentration and also its higher dry matter contribution in the FB:B 2:1 treatment as compared with the other treatments (Bedoussac and Justes, 2010).

The lowest NUtE value (31.5) was found at the faba bean monocrop because of its high $\mathrm{N}$ concentration, which caused higher $\mathrm{N}$ uptake and lower dry matter yield than the other treatments. This means that the faba bean monocrop produced the least biomass per kilogram of $\mathrm{N}$ taken up (Fageria and Baligar, 2005). In contrast, the barley monocrop and the FB:B mixed and 1:1 intercrops showed higher NUtE values ( 63.46 and 60.68 , respectively) than the other treatments. Therefore, barley and its intercrops with faba bean produced the same amount of dry matter with less $\mathrm{N}$, likely because faba bean takes up $\mathrm{N}$ through $\mathrm{N}_{2}$ fixation. A similar response was seen in other studies involving faba bean and other legumes, such as field pea and common vetch, which showed lower NUtE values, and also, in some of the intercrops, NUtE was lower than in the cereal monocrops (Lithourgidis and Dordas, 2010; Dordas and Lithourgidis, 2011).

Crude protein concentration is commonly used to evaluate the quality of forage crops and intercropping systems (Malézieux et al., 2009; Chapagain and Riseman, 2014). The highest $\mathrm{CP}$ concentration was found in the faba bean monocrop, followed by the 2:1 and 2:2 FB:B intercrops, and the lowest $\mathrm{CP}$ concentration was found in the barley monocrop. CP concentration depends on the soil's available $\mathrm{N}$, and the differences among the intercropping treatments could be larger at poor soils and soils with no N inputs (Bedoussac and Justes, 2010, 2011). CP yield followed a trend similar to that seen for CP concentration and was the highest in faba bean monocrop, followed by the FB:B 2:1 intercrop. Also, these differences can be because of the differences in dry matter yield and CP concentration of the different intercropping systems. In contrast, other studies reported no differences regarding the $\mathrm{CP}$ yield among the various intercrops and their monocrops (Li et al., 2006; Lithourgidis et al., 2011b; Dordas et al., 2012; Chapagain and Riseman, 2014). In addition, increase in $\mathrm{CP}$ concentration and $\mathrm{CP}$ yield was found in other studies because of the increase in faba bean's contribution, and this is one of the most important reasons to include a legume in an intercropping system (Osman and Nersoyan, 1986; Berkenkamp and Meeres, 1987; Carr et al., 2004; Bedoussac et al., 2015; Brooker et al., 2015).

\section{Nitrogen uptake rate}

There was an increase in $\mathrm{N}$ uptake rate by cereals and their intercrops from the first sampling (tillering) to the third sampling (anthesis) and then there was a decrease. The initial growth $(\alpha)$ of the cereal was higher at the barley monocrop because of the lower competition from faba bean (Lithourgidis et al., 2011b). The lower initial growth was found at the FB:B 2:1 because of the competition from faba bean and the higher ratio of faba bean and the higher growth rate was found at the FB:B 2:1 and FB:B 1:1. The growth rate for faba bean was higher at the faba bean monocrop and lower for the mixed treatment which is because of the competition from barley. In addition, the higher growth rate was found for barley at four weeks and in faba bean at six weeks and this is possible because faba bean matures later than barley and $\mathrm{N}$ uptake continues for a longer period of time (Karpenstein-Machan and Stuelpnagel, 2000). On the other hand, in all cases where faba bean was intercropped with cereals $\mathrm{N}$ uptake of faba bean was lower than in the faba bean monocrop, probably because of the low dry matter yield of faba bean in the mixtures and the lower contribution of faba bean on the mixture.

\section{Nitrogen nutrition index}

The intercropping of faba bean with barley also affected the NNI of barley. The effect can be positive or neutral depending on the treatment. The highest increase in NNI for barley was found at the FB:B 2:2 and FB:B 2:1 treatment which means that there was a facilitation effect on barley. This process was not studied further here, but it is possible that faba bean has a strong and deep taproot and can modify the rooting system of barley, enabling it to explore a larger volume of soil and to obtain more $\mathrm{N}$ (Jamont et al., 2013). Other also found that legumes can transfer $\mathrm{N}$ to non-legumes and can make a relevant contribution to N nutrition (Génard et al., 2016; Verret et al., 2017; Tsialtas et al., 2018).

\section{Competition indices}

In all intercrops, the $\mathrm{LER}_{\text {faba bean }}$ values were lower than 0.5 , while the LER barley values were higher than 0.5 , which shows that barley had an advantage over faba bean and faba bean had a disadvantage in these intercropping systems (Mead and Willey, 1980). There was a yield advantage of intercrops over monocrops as total LER was higher than 1.0 for the FB:B 2:1 intercrop (1.08). More specifically, this means that a monocropping system will require up to $8 \%$ more land area to produce the same dry matter yield as an intercropping system (FB:B 2:1 intercrop). This indicates greater land use efficiency for FB:B 2:1 intercrop than for monocrops (Midya et al., 2005; Agegnehu et al., 2006). This significant yield advantage of the FB:B 2:1 intercropping system over monocrops can be because of the better land utilization and the better use of the environmental resources for plant growth because of their better arrangement (Banik et al., 2006; Chapagain and Riseman, 2014). Similarly, high LER values for various intercropping arrangements have been reported in other studies (Chen et al., 2004, Banik et al., 2006).

The LER values for dry matter yield and for $\mathrm{N}$ yield (LERN) can be used to quantify the intercrop productivity of an intercropping system but is not used to interpret interference (Bedoussac and Justes, 2011). In the present study, the LERN values of intercrops reached up to 1.23 , which shows that the specific intercrops can increase the use of $\mathrm{N}$ sources by up to $23 \%$. In addition, in all treatments,

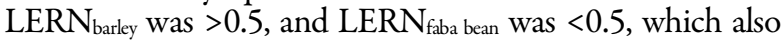
indicates that barley was much more competitive than faba bean in terms of taken up $\mathrm{N}$ from the soil. Barley is a species that has a root system that grows more quickly and deeply and also exhibits earlier $\mathrm{N}$ uptake and higher $\mathrm{N}$ demand than faba bean, as observed in others cereal grain-legume intercrops (Hauggaard-Nielsen et al., 2003; Jensen et al., 2010; Bedoussac and Justes, 2011; Neugschwandtner and Kaul, 2015). 
The results presented in this study are in agreement with other studies which reported LERN values $>1$ for winter cereal-legume intercropping systems (Hauggaard-Nielsen $e t$ al., 2009; Bedoussac and Justes, 2011; Neugschwandtner and Kaul, 2015; Monti et al., 2016). In addition, the results from this study confirmed the advantage of the intercrop system as compared with the monocrop system in terms of $\mathrm{N}$ acquisition, rather than biomass production, as reported by others (Bedoussac and Justes, 2011). These results are probably due to the fact that the legume-cereal intercrops have higher efficiency due to the complementary use of mineral soil $\mathrm{N}$ and atmospheric $\mathrm{N}_{2}$ by the companion species (Bedoussac and Justes, 2010; Jensen $e$ t al., 2010). It was found that cereals are much more competitive than legumes for soil $\mathrm{N}$, and this forces the legumes to rely on $\mathrm{N}_{2}$ fixation and increase the percentage of $\mathrm{N}$ derived from the air as compared with monocropping. Moreover, high LERN values are important in increasing the ecological soundness of modern cropping systems through the use of legumes as a sustainable way to increase soil $\mathrm{N}$ content in low-input agro-systems.

The values of the relative crowding coefficient $(\mathrm{K})$ for barley were greater than those for faba bean in all intercrops, which shows a definite yield advantage for barley compared with faba bean in the intercropping systems that were tested (Banik et al., 2000). In addition, total $\mathrm{K}$ was more than 1.00 in FB:B 2:1, indicating a yield advantage over monocropping for this arrangement (Ghosh, 2004; Dhima et al., 2007). A similar trend was found when $\mathrm{K}$ was calculated based on $\mathrm{N}$ yield.

The $A Y L_{\text {barley }}$ values were positive in all intercrops, which shows a yield advantage for barley, which can be because of the positive effect of faba bean on barley in the intercrops. AYL is an index that can provide more precise information about the inter- and intra-specific competition between the component crops than the other indices (Banik et al., 2000). In addition, partial AYL can be used to quantify the loss or gain of dry matter yield because of the association with other species or the variation of sowing density, which cannot be done with the use of partial LERs. Therefore, partial AYL values were observed to be positive for barley and negative for faba bean, which indicates a significant increase in dry matter yield for barley in the intercrops. Only the FB:B 2:1 intercrop had positive total AYL, and this indicates an advantage on the part of intercropping over monocropping, which agrees with LER results. When AYL was calculated based on $\mathrm{N}$ yield, it was found that $A Y L N_{\text {faba bean }}$ was negative and $A Y L N_{\text {barley }}$ was positive, which indicates that barley was the dominant species in terms of the $\mathrm{N}$ accumulated in the shoots as compared with faba bean. This is probably because barley has a more quickly and deeply growing root system and takes up more $\mathrm{N}$ earlier as compared with faba bean, which fixes $\mathrm{N}_{2}$ from the atmosphere (Hauggaard-Nielsen et al., 2009; Bedoussac and Justes, 2011; Bedoussac et al., 2015).

The highest SPI value was found in FB:B 2:1, which agrees with LER and $\mathrm{K}$ which had also the highest values. In addition, the high SPI values were largely determined by the type of FB:B intercrops because they were not significantly reduced by the intercropping systems which shows a much higher productivity of these intercropping rystems (Agegnehu et al., 2006; Lithourgidis et al., 2011b).

Overall, the indices that were used (LER, K, AYL, and SPI) for dry matter and N yield showed that the FB:B 2:1 intercrop had a significant yield advantage over the other intercrops which is due to its better utilization of environmental resources. Moreover, faba bean showed good adaptability, higher dry matter yield and lodging resistance as compared with other annual legumes which are grown in the same area (Lithourgidis et al., 2006; Lithourgidis et al., 2011b; Dordas et al., 2012). These results agree with those of other studies showing that in an intercropping system, legumes do not benefit as greatly as the non-legumes. In the present study, barley was the dominant species in all intercropping systems. Similarly, other studies have shown that often, legumes are dominated by non-legumes (Banik $e t$ al., 2006).

\section{Economic indices}

The intercropping advantage (IA) is an index that shows the economic feasibility of intercropping systems and is used to find the most advantageous intercrops. The IA was positive only for FB:B 2:1, clearly indicating the yield advantages of this intercropping system over the monocropping systems that had the highest values. The monetary advantage index (MAI) followed a similar trend to that of IA, showing a clear gain for the FB:B 2:1 intercrop, with positive value and negative values for the other intercrops. The intercropping system FB:B 2:1 had the highest values for MAI and IA which is because of the better utilization of environmental resources.

\section{Conclusions}

Although faba bean was not studied in intercropping systems with different arrangements with barley, the results of this study show that faba bean can be grown with barley because these plants showed a high dry matter and $\mathrm{N}$ yield that was comparable to the yield seen in other intercropping studies with common vetch, red pea, and field pea and winter cereals grown in the same area. In addition, by exploiting the available growth resources, FB:B intercrops achieved a yield advantage as compared with their respective monocrops. Moreover, among the intercropping treatments, FB:B 2:1 was found to be profitable, and this, together with the results obtained from NNI, the competition and economics indices, indicated an advantage over monocrops in terms of dry matter and $\mathrm{N}$ yield. This study demonstrated that the intercropping of faba bean and barley using various spatial arrangements leads to improved land productivity, $\mathrm{N}$ yield and economic returns and can be used in the development of sustainable crop production systems.

\section{Acknowledgements}

This work has been supported by ReMIX - project which has received funding from the European Union's Horizon 2020 Programme for Research \& Innovation under grant agreement $\mathrm{n}^{\circ} 727217^{\prime \prime}$. 
1126

\section{Conflict of Interest}

The authors declare that there are no conflicts of interest related to this article.

\section{References}

Agegnehu G, Ghizaw A, Sinebo W (2006). Yield performance and land-use efficiency of barley and faba bean mixed cropping in Ethiopian highlands. European Journal Agronomy 25(3):202-207.

Anil L, Park J, Phipps RH, Miller FA (1998). Temperate intercropping of cereals for forage: a review of the potential for growth and utilization with particular reference to the UK. Grass Forage Science 53(4):301317.

Banik P, Sasmal T, Ghosal PK, Bagchi DK (2000). Evaluation of mustard Brassica campestris var. Toria and legume intercropping under 1:1 and 2:1 row-replacement series systems. Journal of Agronomy and Crop Science 185(1):9-14.

Banik P, Midya A, Sarkar BK, Ghose SS (2006). Wheat and chickpea intercropping systems in an additive series experiment: Advantages and weed smothering. European Journal Agronomy 24(4):325-332.

Bedoussac L, Justes E (2010). Dynamic analysis of competition and complementarity for light and $\mathrm{N}$ use to understand the yield and the protein content of a durum wheat-winter pea intercrop. Plant and Soil 330(1-2):37-54.

Bedoussac L, Justes E (2011). A comparison of commonly used indices for evaluating species interactions and intercrop efficiency: Application to durum wheat-winter pea intercrops. Field Crops Research 124(1):2536.

Bedoussac L, Journet E-P, Hauggaard-Nielsen H, Naudin C, Corre-Hellou G, Steen Jensen E, ... Justes E (2015). Ecological principles underlying the increase of productivity achieved by cereal-grain legume intercrops in organic farming. A review. Agronomy for Sustainable Development 35(3):911-935.

Berkenkamp B, Meeres J (1987). Mixtures of annual crops for forage in central Alberta. Canadian Journal of Plant Science 67(1):175-183.

Brooker RW, Bennett AE, Cong W-F, Daniell TJ, George TS, Hallett PD, ... White PJ (2015). Improving intercropping: a synthesis of research in agronomy, plant physiology and ecology. New Phytologist 206(1):107117.

Carr PM, Horsley RD, Poland WW (2004). Barley, oat and cereal-pea mixtures as dryland forages in the Northern Great Plains. Agronomy Journal 96(3):677-684.

Chapagain T, Riseman A (2014). Barley-pea intercropping: Effects on land productivity, carbon and nitrogen transformations. Field Crops Research 166:18-25.

Chen C, Westcott M, Neill K, Wichman D, Knox M (2004). Row configuration and nitrogen application for barley-pea intercropping in Montana. AgronomyJournal 96(6):1730-1738.

Dhima KV, Lithourgidis AS, Vasilakoglou IB, Dordas CA (2007). Competition indices of common vetch and cereal intercrops in two seeding ratio. Field Crops Research 100(2-3):249-256.

Dordas CA, Lithourgidis AS (2011). Growth, yield and nitrogen performance of faba bean intercrops with oat and triticale at varying seeding ratios. Grass Forage Science 66(4):569-577.

Dordas CA, Vlachostergios DN, Lithourgidis AS (2012). Growth dynamics and agronomic-economic benefits of pea-oat and pea-barley intercrops. Crop Pasture Science 63(1):45-52.

Dumanski J, Coote D, Lucerek G, Lok C (1986). Soil conservation in Canada.Journal of Soil and Water Conservation 41(4):204210.

Esmaeili A, Sadeghpour A, Hosseini SMB, Jahanzad E, Chaichi MR, Hashemi M (2011). Evaluation of seed yield and competition indices for intercropped annual medic-barley. International Journal of Plant Production 5(4):395-404.

Fageria NK, Baligar VC (2005). Enhancing nitrogen use efficiency in crop plants. Advances of Agronomy 88:97-185.

Field A (2009). Discovering statistics using SPSS. Thousand Oaks, California. Sage Publications Inc.

Génard T, Etienne P, Laîné P, Yvin J-C, Diquélou S (2016). Nitrogen transfer from Lupinus albus L., Trifolium incarnatum L. and Vicia sativa L. contribute differently to rapeseed (Brassica napus L.) nitrogen nutrition. Heliyon 2(9):e00150.

Ghosh PK (2004). Growth, yield, competition and economics of groundnut/cereal fodder intercropping systems in the semi-arid tropics of India. Field Crops Research 88(2-3):227-237.

Hair J, Anderson R, Tatham R, Black W (1995). Multivariate data analysis with readings. New Jersey: Prentice-Hall International, Inc.

Hauggaard-Nielsen H, Ambus P, Jensen ES (2003). The comparison of nitrogen use and leaching in sole cropped versus intercropped pea and barley. Nutrient Cycling in Agroecosystems 65(3):289-300.

Hauggaard-Nielsen H, Ambus P, Jensen ES (2001). Interspecific competition, $\mathrm{N}$ use and interference with weeds in pea-barley intercropping. Field Crops Research 70(2):101-109.

Hauggaard-Nielsen H, Gooding M, Ambus P, Corre-Hellou G, Crozat Y, Dahlmann C, ... Jensen ES (2009). Pea-barley intercropping and shortterm subsequent crop effects across European organic cropping conditions. Nutrient Cycling Agroecosystems 85(2):141-155.

Herbert SJ, Putman DH, Poos-Floyd ML, Vargas A, Creighton JF (1984). Forage yield of intercropped corn and soybean in various planting patterns. Agronomy Journal 76(4):507-510.

Jamont M, Piva G, Fustec J (2013). Sharing N resources in the early growth of rapeseed intercropped with faba bean: does $\mathrm{N}$ transfer matter? Plant and Soil 371(1-2):641-653.

Jensen ES, Peoples MB, Hauggaard-Nielsen H (2010). Faba bean in croppingsystems. Field Crops Research 115:203-216.

Justes E, Jeuffroy MH, Mary B (1997). Wheat, barley and durum wheat. In: Lemaire G (Ed). Diagnosis of the nitrogen status in crops SpringerVerlag, Berlin, Heidelberg, Germany pp 73-91.

Karlidag H, Yildirim E (2007). The effects of nitrogen fertilization on intercropped strawberry and broad bean. Journal of Sustainable Agriculture 29(4):61-74.

Li L, Sun J, Zhang F, Guo T, Bao X, Smith FA, Smith SE (2006). Root distribution and interactions between intercropped species. Oecologia 147(2):280-290.

Lithourgidis AS, Vasilakoglou IB, Dhima KV, Dordas CA, Yiakoulaki MD (2006). Forage yield and quality of common vetch mixtures with oat and triticale in two seeding ratios. Field Crops Research 99(2-3):106113. 
Lithourgidis AS, Dordas CA (2010). Forage yield, growth rate and nitrogen uptake of wheat, barley and rye-faba bean intercrops in three seeding ratios. CropScience 50(5):2148-2158.

Lithourgidis AS, Dordas CA, Damalas CA, Vlachostergios DN (2011a). Annual intercrops: an alternative pathway for sustainable agriculture. Australian Journal ofCrop Science 5(4):396410.

Lithourgidis AS, Vlachostergios DN, Dordas CA, Damalas CA (2011b). Dry matter yield, nitrogen content, and competition in pea-cereal intercropingsystems. European Journal of Agronomy 34(4):287-294.

López-Bellido RJ, López-Bellido L (2001). Efficiency of nitrogen in wheat under Mediterranean conditions: effect of tillage, crop rotation and $\mathrm{N}$ fertilization. Field Crops Research 71(1):31-46.

Malézieux E, Crozat Y, Dupraz C, Laurans M, Makowski D, OzierLafontaine H, ... Valantin-Morison M (2009). Mixing plant species in cropping systems: concepts, tools and models. A review. Agronomy of Sustainable Development 29:43-62.

Midya A, Bhattacharjee K, Ghose SS, Banik P (2005). Deferred seeding of blackgram Phaseolus mungo L. in rice Oryza sativa L. field on yield advantages and smothering of weeds. Journal of Agronomy of Crop Science 191(3):195-201.

Mead R, Willey RW (1980). The concept of a land equivalent ratio and advantages in yields for intercropping. Experimental Agriculture 16(3):217-228.

Monti M, Pellicanò A, Santonoceto C, Preiti G, Pristeri A (2016). Yield components and nitrogen use in cereal-pea intercrops in Mediterranean environment. Field Crops Research 196:379-388.

Neugschwandtner RW, Kaul H (2015). Nitrogen uptake, use and utilization efficiency by oat-pea intercrops. Field Crops Research 179:113-119.
Osman AE, Nersoyan N (1986). Effect of the proportion of species on the yield and quality of forage mixtures, and on the yield of barley in the followingyear. Experimental Agriculture 22(4):345-351.

Sparks DL, Page AL, Helmke PA, Loeppert RH, Soltanpour PN, Tabatabai MA, ... Sumner ME (1996). Methods of soil analysis: Part 3-Chemical methods Agron. Monogr. 9, 2nd ed. ASA and SSSA, Madison, WI.

SPSS (1998). SPSS Base 8.0 user's guide and SPSS applications guide. Chicago, IL.

Steel RGD, Torrie JH, Dickey DA (1997). Principles and procedures of statistics: A biometrical approach. 2nded. McGraw-Hill, New York.

Weigelt A, Jolliffe P (2003). Indices of plant competition. Journal of Ecology 91(5):707-720.

Vandermeer JH (1990). Intercropping. In: Caroll CR, Vandermeer JH, Rosset PM(Eds). Agroecology. McGraw-Hill,New York, pp 481-516.

Verret V, Gardarin A, Makowski D, Lorina M, Cadoux S, Butier A, Valantin-Morison M (2017). Assessment of the benefits of frostsensitive companion plants in winter rapeseed. European Journal of Agronomy 91:93-103.

Vlachostergios DN, Dordas, CA, Lithourgidis AS (2015). Forage yield, protein concentration and interspecific competition in red pea-cereal intercrops. Experimental Agriculture 51(4):635-650.

Ziadi N, Bélanger G, Claessens A, Lefebvre L, Cambouris AN, Tremblay N, ... Parent LE (2010). Determination of a critical nitrogen dilution curve for spring wheat. Agronomy Journal 102(1):241-250. 